\title{
Haplotype Analysis of Ferritin Heavy Chain Affects Stillborn Piglets on Large White X Landrace Crossbred Sows
}

\author{
Nakarin Pripwai \\ Human and Animal Biotechnology, Graduate School, Chiang Mai University, Thailand \\ Center of Excellence on Agricultural Biotechnology: (AG-BIO/PERDO-CHE), Bangkok 10900, Thailand \\ E-mail: nakarinpripwai@hotmail.com \\ Supamit Mekchay (Corresponding author) \\ Department of Animal Science, Faculty of Agriculture, Chiang Mai University, Thailand \\ Human and Animal Biotechnology, Graduate School, Chiang Mai University, Thailand \\ Center of Excellence on Agricultural Biotechnology: (AG-BIO/PERDO-CHE), Bangkok 10900, Thailand
}

Tel: 66-53-944092 ext. $31 \quad$ E-mail: agismkch@chiangmai.ac.th

Received: March 28, $2011 \quad$ Accepted: April 12, $2011 \quad$ Online Published: December 1, 2011

doi:10.5539/jas.v4n1p62 URL: http://dx.doi.org/10.5539/jas.v4n1p62

This research is financial supported by National Center for Genetic Engineering and Biotechnology, National Science and Technology Development Agency, Ministry of Science and Technology (BT-B-01-AG-10-5002), and partially supported by the Center of Excellence on Agricultural Biotechnology, Science and Technology Postgraduate Education and Research Development Office, Office of Higher Education Commission, Ministry of Education (AG-BIO/PERDO-CHE).

\begin{abstract}
The objective of this experiment was to identify the novel SNP on porcine FTH genes. Moreover, their association with litter size traits in commercial pigs will be analyzed. 1,361 Large White x Landrace crossbred sows were bled and DNA was extracted. The records included total number of piglets born (TNB), number of piglets born alive (NBA), number of piglets stillborn (SB) and number of piglets mummified (MM). The PCR primers were designed throughout the porcine $F T H$. PCR products were performed and screened for single nucleotide polymorphisms (SNPs) by using polymerase chain reaction - single strand conformation polymorphism (PCR-SSCP). Consequently, differentially heteroduplex shift were cloned and sequenced. SNPs including c.596C $>\mathrm{T}$, c.634A $>\mathrm{G}$ c.677T $>\mathrm{C}$ and c.699T $>\mathrm{C}$ were found. According to these SNPs, there were proved by PCR-RFLP technique, BsuRI-c.596C $>$ T, Hin6I-c.643A $>$ G, Msp I-c.677T $>$ C and MspI-c.699T $>$ C. Six different haplotypes for the SNPs of MspI at nucleotide position MspI-c.677T $>\mathrm{C}$ and $M s p \mathrm{I}-\mathrm{c} .699 \mathrm{~T}>\mathrm{C}$ were presented. The TCTC haplotype was significantly associated with increasing SB. It was conclude that $M s p I-F T H$ haplotype significantly associated with SB in commercial pigs which may used for marker-assisted selection on pig breeding program.
\end{abstract}

Keywords: Litter size traits, Ferritin heavy chain, PCR-SSCP, Stillborn piglets

\section{Introduction}

Reproductive performance, especially litter size in term of total number of piglet born (TNB) and number of piglet born alive (NBA) are one of the most economically important traits in pig production. It is well known that litter size is affected by a set of factors such as genetics, farm, feeds, season and mating boars, which account for a large part of the phenotype variance. From a genetic point of view, litter size could be controlled by numerous genes in complicated physiological networks such as those affecting ovulation rate, fertilization rate, embryo survival and uterine capacity (Li et al., 2009). Litter size is low heritability approximately 0.09 for NBA that affecting slowly changed in genetic drift (Rothschild, 1996) and difficult to measure phenotypically by traditional breeding method which have used animal selection on the basis of observable phenotype representing the collective effect of all genes and the environment (Merks et al., 2000). Furthermore, litter size trait is sex-limited and is not measurable until sexual maturity (Spötter and Distl, 2006). This breeding method is 
the-state-of-the-art and setback over 3-5 years or up to 10 generation that gain of about 0.6 piglets within-line selection and 0.8 piglets due to immigration (Bolet et al., 2001).

Markers can be used to localize genes responsible for qualitative traits and they can also be sued to detect genes with substantial effects on quantitative traits. In this case the approach is referred to as QTL mapping (de Vries et al., 2000). Indeed, this approach has been used in relation to TNB and NBA. On the other hand, the candidate gene approach can be relatively straightforward compared to the QTL approach. Polymorphisms were used to look for associations across populations, when associations are identified the resulting marker can potentially be used directly in breeding programs (de Vries et al., 2000). Significant QTL regions for litter size are located on SSC8 (King et al., 2003) and on SSC11 (Cassady et al., 2001). Putative QTL regions are located on SSC6 (Wilkie et al., 1999), SSC7, SSC12, SSC14 and SSC17 (de Koning et al., 2001).

Bertani et al. (2004) identified transcriptional candidate genes for fertility in anterior pituitary gland of pigs. Ferritin heavy chain $(F T H)$ was found highly expressed between sows selected for ovulation rate and embryo survival compared with the control line, $42 \%$ and $10 \%$, respectively. FTH is involved in the folate pathway by enhancing expression of serine hydroxymethyltransferase and de novo thymidine biosynthesis (Oppenheim et al., 2001). Supplementation of folic acid during gestation leads to increases in litter size, primarily due to improved embryo and fetal survival (Lindemann, 1993). Ferritin is controlled by a common cytosolic protein, iron regulatory protein, which binds to the iron-responsive element in the 5-prime untranslated region of the $\mathrm{H}$ - and L-ferritin mRNAs (Leibold and Munro, 1988; Eisenstein, 2000). Moreover, Pham et al. (2004) identified FTH, the primary iron storage factor, as an essential mediator of the antioxidant and protective activities of nuclear factor kappa-B. Manipulation of FTH by knock-out method in the mouse affected on lethal during embryonic development (Ferreira et al., 2001). FTH was characterized as a novel modulator in TGF- $\beta 1$-induced epithelial-mesenchymal transition. In response to TGF-beta1, there was a dramatic decrease in the FHC levels, which caused iron release from FHC and, therefore, increased the intracellular labile iron pool (Zhang et al., 2009). Nucleotide sequence of porcine $F T H$ has been identified (GenBank accession No. NM 213975.1) and was mapped on Ssc2p14-17 between the loci SW2443 and SW240 with distances of 42.8 and $20.2 \mathrm{cM}$ on the sex averaged map (Ponsuksili et al., 2002) that encode the 181 amino acids. The FTH gene is a good candidate gene for fecundity in mammalians. However the information on FTH marker for litter traits of pig is limited. Then, the aims of this study were to identify the novel SNP on porcine FTH genes. Moreover, their association with litter size traits in commercial pigs would be analyzed.

\section{Materials and Methods}

\subsection{Animals and data}

A totally 1,361 Large White X Landrace crossbred commercial sows including 5,102 parities were bled and recorded in terms of TNB which was calculated as NBA plus SB and plus MM on $1^{\text {st }}$ parity to $5^{\text {th }}$ parity for association study, the descriptive statistics was shown as table 1 . Primary data were plotted and 20 sows were selected form extremely tails of population into 2 groups; $10 \mathrm{High}-(>15$ piglets/litter) and 10 low sows ( $<8$ piglets/litter) for screening SNPs. Associated study was analyzed between candidate gene and phenotypic traits. Litter size trait was analyzed as TNB and NBA. Mortality traits were SB and MM.

Blood samples were collected from jugular vein with $0.5 \mathrm{M}$ EDTA anti-coagulant and extracted by using Chelex ${ }^{\circledR}$. Briefly, $20 \mu \mathrm{l}$ of blood was lysed twice, centrifuge at 2,000 rpm $1 \mathrm{~min}$, added Chelex ${ }^{\circledR}$ solution over the pellet and incubated overnight. The solution samples were boiled at $95^{\circ} \mathrm{C}$ for 5 minutes and stored at $4{ }^{\circ} \mathrm{C}$ until analyzed (Walsh et al., 1991).

\subsection{Polymerase Chain Reaction-Single Strand Conformation Polymorphism}

The polymerase chain reaction-single strand conformation polymorphisms (PCR-SSCP) were used to screen SNPs (Orita et al., 1997) on nucleotide sequence of porcine FTH genes. Briefly, amplification by PCR was performed with primers (Table 2). Standard PCR was performed in a final reaction volume of $20 \mu \mathrm{l}$ by using 50.0 ng of genomic DNA sample, $1 \mathrm{X} \mathrm{NH}_{4} \mathrm{SO}_{4}$ buffer, $0.4 \mu \mathrm{mol}$ of primer, $0.5 \mu \mathrm{l}$ of $0.2 \mathrm{mmol} \mathrm{dNTPs}, 1.5 \mathrm{mmol}$

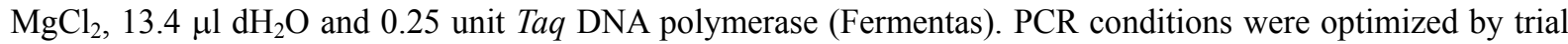
and error technique. For verification prior to SSCP analysis, PCR products of the expected size were visualized on ethidium bromide-stained $6 \%$ polyacrylamide gels. The PCR products were denatured for 4 min at $95^{\circ} \mathrm{C}$ and immediately chilled on ice before loading to the SSCP gel. Five and 10\% polyacrylamide (49:1 acrylamide to bis-acrylamide) with or without 5\% glycerol TBE gels are run with $1 \mathrm{X}$ TBE on a vertical electrophoresis system with or without ice bath and constant power at $50 \mathrm{~mA}$ and $100 \mathrm{~V}$ for $3 \mathrm{hrs}$. Acrylamide concentration and temperature were optimized for each fragment to obtain maximum separation of allelic variations. Gels were stained by Silver Staining Standard Protocol and dried by Gel Slab ${ }^{\circledR}$ for $4 \mathrm{hr}$ at $55^{\circ} \mathrm{C}$. 


\subsection{Cloning and sequencing}

PCR product would be cloned into pGEM-T Easy Vector system. The cloned PCR fragment compared with PCR product obtained from genomic DNA. Three clones with the same size of inserted fragment would be sequenced on the CEQ ${ }^{\mathrm{TM}} 8000$ Genetic Analysis System, Beckman Coulter by using GenomeLab ${ }^{\mathrm{TM}}$ DTCS Quick Start Kit (Beckman Coulter, USA).

\subsection{Polymerase Chain Reaction-Restriction Fragment Length Polymorphism}

After the common sequence variations observed in a population have been determined by DNA sequencing, PCR strategies could be designed to elucidate the particular allele present in each individual sample. Similarly, amplification of a region surrounding a naturally occurring restriction enzyme site, followed by digestion with the appropriate enzyme, can allow a rapid genotyping determination to be performed. $6 \%$ polyacrylamide gel was stained by silver staining standard protocol and visualized genotyping.

\subsection{Statistic analysis}

Allele and genotype frequencies of FTH were determined by the total count of an allele and genotype divided by twice the number of observations. The genotype frequencies of polymorphisms were examined for deviations from Hardy-Weinberg equilibrium by $\chi^{2}$ tests. Test of linkage disequilibrium between pairwise genotype combinations of the SNPs were also performed using $\chi^{2}$ procedure. Association of SNP markers with litter size were analyzed with general linear model included fixed effect of genotype, breed and parity number, and residual as following: $\mathrm{Y}_{\mathrm{ijk}}=\mu+$ genotype $_{\mathrm{i}}+$ parity $_{\mathrm{k}}+\mathrm{e}_{\mathrm{ijk}}$, where $\mu$ denoted the average normalized of population; genotype $\mathrm{i}_{\mathrm{i}}$ denoted the fixed effect of genotype $i$; breed $_{\mathrm{j}}$ denoted the fixed effects of breed $j$; parity $_{\mathrm{k}}$ denoted the fixed effect of parity $k$; and $\mathrm{e}_{\mathrm{ijk}}$ denoted the residual effects of genotype $i$, breed $j$ and parity $k$.

\section{Results}

\subsection{Discovered SNPs novel of FTH gene}

PCR-SSCP was used to screen SNPs on nucleotide sequence of porcine FTH gene. The PCR products were denatured at $95^{\circ} \mathrm{C}$ for $4 \mathrm{~min}$ and immediately chilled on dried ice before loading to the SSCP gel. Five and $10 \%$ polyacrylamide (49:1 acrylamide to bis-acrylamide) with or without $5 \%$ glycerol TBE gels were ran with $1 \mathrm{X}$ TBE on a vertical electrophoresis system with or without ice bath and constant power at $50 \mathrm{~mA}$ and $120 \mathrm{~V}$ for 3 hrs. Acrylamide concentration and temperature were optimized for each fragment to obtain maximum separation of allelic variations. Gels were stained by silver staining standard protocol and dried by Gel Slab® for $3 \mathrm{hr}$ at $55^{\circ} \mathrm{C}$. The polymorphism of $F T H$ was shown as Figure 1. Lane 10 showed differentially heteroduplex shift between low- and high-TNB sows. Subsequently, Lane 10 polymorphic band was selected to clone into pGEM-T Easy Vector System and sequence analyzed on the CEQ ${ }^{\mathrm{TM}} 8000$ Genetic Analysis System, Beckman Coulter by using GenomeLab ${ }^{\mathrm{TM}}$ DTCS Quick Start Kit (Beckman Coulter, USA). The sequences were screened homology with BLAST software (Altschul et al., 1997).

Four SNPs in FTH were found including BsuRI-c.596C $>$ T, Hin6I-c.643A $>$ G, MspI-c.677T $>\mathrm{C}$ and $M s p$ I-c.699T $>$ C. Consequently, these polymorphic sites were proved by using PCR-RFLP technique in extremely low- and high-TNB of sampling population. Similarly, $2.5 \mu \mathrm{l}$ of the PCR product of c.596C $>\mathrm{T}$, c.634A $>\mathrm{G}$ and c.699T $>C$ was digested with 0.25 units of BsuRI, Hin $6 \mathrm{I}$ and $M s p \mathrm{I}$, respectively, by manufacturing instruction. The PCR-RFLP fragments of each candidate genes were ran on $6 \%$ polyacrylamide gel electrophoresis and stained with standardized silver staining protocol. BsuRI-c.596C $>$ T and Hin6I-c.634A $>$ G polymorphism were not significantly between low- and high-TNB sows. On the other hand, the only 6 different haplotypes for the SNPs of MspI-FTH at nucleotide position c.677T $>\mathrm{C}$ and c.699T $>\mathrm{C}$ were presented.

\subsection{Genotype and allele frequencies for the investigated SNPs for FTH gene}

Frequencies for the $F T H$ gene in 1,361 parent stock of commercial sows with 5,102 parity records in Thailand were shown in Table 3. TT, TC and $C C$ allele frequency was $0.22,0.35$ and 0.43 , respectively. The haplotype frequencies of the two SNPs were not distributed according to Hardy-Weinberg equilibrium proportion $(\mathrm{P}<0.01)$. Therefore, the population is in linkage disequilibrium at these haplotypes under consideration $(\mathrm{P}<0.01)$.

\subsection{Association study between FTH genotype and litter size related traits}

The association between MspI-FTH haplotype and litter size traits in terms of TNB, NBA, SB and MM piglets were analyzed as shown as Table 4. The unfavorable TC/TC haplotype was significantly higher SB than other haplotypes. No associated effects between $M s p \mathrm{I}-F T H$ haplotypes and litter size traits were found including TNB, NBA and MM. 


\section{Discussions and Conclusions}

Compared with 12,599 Thai Landrace sows recorded between's 1993-2005, TNB and SB was 10.03 \pm 2.64 and $0.21 \pm 0.59$ (Imboonta et al., 2007). While, Moeller et al., (2004) stated between's 1997-1999 that TNB was $11.05 \pm 1.49$, with range $1-25$ pigs, and NBA was $9.96 \pm 1.38$, with range $0-21$ pigs. In present study, 2006-2008, 1,361 Large White $x$ Landrace sows records showed $11.30 \pm 3.00,10.02 \pm 3.00$ and $0.88 \pm 1.14$ piglets/litter in TNB, NBA and SB, respectively. These parameters exhibited the genetic progress in Thai's swine commercial that tended to be favorable for white breeds and widely used by the commercial to produced $\mathrm{F}_{1}$ crossbred gilts resulting from imported nucleus herd. However, SB may increase in order to improvement. Addition, the main direction of selection for this founder pigs was the meat deposition in carcass and growth rate, but was not considered in the piglet number and its related traits.

\subsection{SNPs discovery techniques}

PCR-SSCP technique could be detected DNA polymorphisms and mutations at multiple places in DNA fragments. The principle of this method was based on the fact that the electrophoretic mobility of nucleic acids in non-denaturing gels was sensitive to both size and shape (Orita et al., 1997). Unlike double strand DNA, single strand DNA was flexible and would adopt a conformation determined by intramolecular interactions and base stacking that was uniquely dependent on sequence composition (Orita et al. 1989). This conformation could be affected when even a single base is changed. Conformational changes could be detected as alterations in the electrophoretic mobility of the single-stranded DNA in non-denaturing polyacrylamide gels (Armersham, 1998). As a mutation scanning technique, though, PCR-SSCP was more often used to analyze the polymorphisms at single locus (Sunnucks et al., 2000). The SSCP technique has proven useful for detection of mutations and polymorphisms in a number of studies (Hayashi, 1992; Skinner et al., 1996; Orita et al., 1997). Although, this technique has limitations, detection of single base substitutions is less sensitive in larger DNA fragments (Fujita and Silver, 1994). In present study, the primers designed were not exceeded $300 \mathrm{bp}$ and the PCR fragments were separated on a 6,9 and $12 \%$ of acrylamide:bis-acryamide (49:1) concentration and 5\% additive glycerol for sensitivity to detect single-base changes (Orita et al., 1989). The classical PCR-SSCP analysis for the detection of mutation was found in the CYP11B1 gene (Skinner et al., 1996). Moreover, two PCR-SSCP polymorphisms, a $\mathrm{T}-\mathrm{C}$ transition in the third exon and an A-C transversion in the fifth exon were found that positive associated with milk production traits in dairy cattle (Yao et al., 1996). In addition, PCR-SSCP polymorphism in exon 10 of growth hormone receptor associated with average daily gain from birth to weaning in sheep (Valeh et al., 2009).

\subsection{FTH polymorphisms discovery and association}

In the present study, candidate genes were chosen because they have been shown to be involved in the regulation of metabolism. These functions seemed the most likely to have an effect on the litter size merit of the animals. SNPs within this gene were examined for effects on these traits in commercial sows. FTH was chosen based on their biological functions to be evaluated for association between polymorphisms and litter traits, because of differentially expressed gene in the anterior pituitary gland of sows selected of long-term for increased ovulation rate and embryo survival that was confirmed by using Northern hybridization (Bertani et al., 2004), and the ferroxidase activity of the ferritin molecule which could transform the more toxic $\mathrm{Fe}$ (II) into the less toxic Fe(III) that was essential for detoxification of iron and/or for maintaining its bioavailability during embryonic development (Ferreira et al., 2000). These functions seemed the most likely to have an effect on the fetuses development. Developing fetuses must depend on iron crossing the maternoplacental barrier that was accomplished via endometrial secretion of uteroferrin. Uteroferrin secreted by the endometrium was taken up by the areolae of the placenta and released to fetal circulation that is binding receptor at fetal liver. The $\mathrm{Fe}$ of the uteroferrin molecule was used for hemoglobin formation and liver was the primary site for hematopoiesis activity in developing fetuses (Mahan and Vallet, 1997). The highest level of FTH gene expression at 9.5 days of gestation was found in the heart suggests that the embryos could also die of heart failure because of massive iron deposition (Ferreira et al., 2000). While, $F T H^{-\alpha}$ mutant embryo survive at least to the 62-cell stage that should have enough iron to ensure DNA replication and heme systhesis (Ferreira et al., 2000). Disruption of uroporphyrinogen III synthase was lethal between 2- and 4-cells stage, suggesting that heme synthesis takes place at very early stages (Bensidhoum et al., 1998) and the faster blood cell development on early gestation period could be beneficial to fetal survival in swine (Vallet et al., 2003). Moreover, FTH is involved in the folate pathway by enhancing expression of serine hydroxymethyltransferase and de novo thymidine biosynthesis (Oppenheim et al, 2001). The role of FTH in modulating intracellular free iron concentrations, and its ability to enhance the expression of a cytoplasmic serine hydroxymethyltransferase (cSHMT), may enable coordinate regulation of folate and iron metabolism and potentially enable the regulation of one-carbon metabolism by iron (Woeller et al., 2007). CUGBP1, a protein known to interact with the $\alpha$ and $\beta$ subunits of eukaryotic initiation 
factor2, binds to its consensus sequence on the 3'-UTR of cSHMT and ferritin, which has been shown to bind mRNA at 5'-UTR. The physical interaction between CUBGP1and FTH recruits the translation initiation machinery to the cSHMT IREs (Woeller et al., 2007). Supplementation of folic acid during gestation leads to increases in litter size traits, primarily due to improved embryo and fetal survival (Lindemann, 1993). A day 24-40 of gestation is a critical time progression for fetal erythropoiesis in pigs as well as survival in a crowded uterine environment. The uterine environment had little overall effect on erythropoiesis in white crossbreed pigs but did affect fetal survival, and crowding may compromise erythropoiesis in small fetuses (Pearson et al., 1998). Selection for increased ovulation rate has been very successful. However, the increased in ovulation rate did not result in increases in litter size (Wilson et al., 1999). Selection for uterine capacity improved fetal survival primarily during the time period between $\mathrm{d} 25$ and d 45 that had a significant influence on subsequent fetal growth and survival in a crowed uterine environment (Freking et al., 2007).

Johnson et al. (1999) showed strong evidence of a genetic component to embryonic survival $\left(\mathrm{h}^{2}=0.14\right)$ and a positive genetic correlation with litter size $\left(\mathrm{r}_{\mathrm{g}}=0.35\right)$ that increased SB and MM fetuses (Freking et al., 2007), however, MM sows were not significantly difference in this study. Moreover, several factors, such as parity, piglet birth weight, sex and birth assistance have been shown to be associated with variations in SB (Canario et al., 2006). In fact, the excessively high ovulation rate of these animals may result in uterine crowding and excessive competition for nutrients and oxygen, which may negatively affect the growth rate and body composition of the survivor (Vonnahme et al., 2002). SNPs within FTH gene was examined for effects on these traits in commercial sows.

However, the informations of FTH marker for piglet number and mortality traits in pig were limited. Present study, FTH primers were designed throughout mRNA sequence (accession No. NM213975.1). FTH was amplified from genomic DNA using PCR. The PCR products were screening for polymorphisms by using PCR-SSCP. Heteroduplex were found and cloned into pGEM-T Easy Vector System and subsequently automated sequencing on the $\mathrm{CEQ}^{\mathrm{TM}} 8000$ Genetic Analysis System, Beckman Coulter by using GenomeLab ${ }^{\mathrm{TM}}$ DTCS Quick Start Kit (Beckman Coulter, USA). The sequences are screened homology with BLAST software (Altschul et al., 1997) and genotyping by using PCR-RFLP technique. Monomorphism was found in BsuRI-c. 596C $>\mathrm{T}$ and Hin6I-c.634A $>$ G. The novel SNPs were found in $M s p \mathrm{I}-\mathrm{c} .677 \mathrm{~T}>\mathrm{C}$ and $M s p \mathrm{I}-\mathrm{c} .699 \mathrm{~T}>\mathrm{C}$ haplotype polymorphism which occurred in 3'-UTR of FTH. Element in the 3'-UTR and the poly (A) tail of many genes have been shown to influence translation either positively or negatively (Woeller et al., 2007). All of new polymorphisms detected in the current study were in the exonic region, indicating that the exonic region of the $F T H$ gene are much more variable than the intronics, in the porcine $F T H$ located at c.677T $>\mathrm{C}$ and c.699T $>\mathrm{C}$ of exon 3. Thus far, only one exonic polymorphism has been detected in the pig (Ponsuksili et al., 2002). Detected polymorphisms occurred in 3'-UTR of FTH which perhaps the target binding site of micro RNA (miRNA) that mRNA translation was inhibited or mRNA was degraded (Williams, 2008).

The magnitude of the differences in genotype distribution of homozygous TTTT and CCCC haplotypes was low frequency as well as 42 and 166 animals, respectively. The effects of selection, different frequencies in the founder pigs, and random genetic drift could have caused allele frequencies to differ within this population. Random genetic drift is a non-directional force that acted to change allele frequencies and random genetic drift alone caused the order of favorable allele frequencies of this locus. In the absence of selection, the amount of drift depends on allele frequencies and effective population size (Linville et al., 2001). After drift begins, it is most probable that an allele frequency would be continued to change in the same direction (Falconer and Mackay, 1996). The genotype frequencies of the two SNPs were not distributed according to Hardy-Weinberg equilibrium proportions $(\mathrm{P}<0.01)$. Pairwise comparison of haplotype of $M s p \mathrm{I}-\mathrm{c} .677 \mathrm{~T}>\mathrm{C}$ and $M s p \mathrm{I}-\mathrm{c} .699 \mathrm{~T}>\mathrm{C}$ revealed the existence of significant linkage disequilibrium between the SNPs $(\mathrm{P}<0.01)$.

Both SNPs haplotype showed associations with mortality traits that SB with TCTC haplotype was 19.27 and $25.69 \%$ higher than homozygous TTTT and CCCC haplotype $(\mathrm{P}<0.04)$, respectively, and was 18.35 and $22.94 \%$ higher than heterozygous TTTC and TCCC haplotype $(\mathrm{P}<0.04)$, respectively. The piglet number and its related traits were decline on subsequent parity (Imboonta et al., 2007). Here, TCTC haplotype was significantly focused on SB that were due to effects of uterine environment in late gestation, length of the farrowing period, and management at parturition, that may result in SB pigs (Moeller et al., 2004). Iron deficiency, however, is asscociated with an increased incidence of SB in pigs (Moore et al., 1965). The availability of iron during erythropoiesis is a critical aspect of mammalian homeostasis (Tori and Tori, 2002). Although no evidence exists for a link between FTH haplotype and increased incidence of SB, it is possible that alterations in iron homeostasis are involved (Bertani et al., 2004). Moreover, mitochondrial ferritin may be induced under conditions of pathologic iron accumulation in heme-synthesizing cells (Tori and Tori, 2002). Interestingly, 
transient transfection assays demonstrated that ferritin $\mathrm{H}$ repressed synthesis of the beta-globin, suggesting that ferritin may play a role in hemoglobin switch (Broyles et al., 2001).

This FTH candidate gene study concluded that BsuRI-c.596C $>$ T and Hin6I-c.634A $>$ G monomorphisms were found. Novel haplotype analysis of MspI-c.677T $>\mathrm{C}$ was found together with $M s p \mathrm{I}-\mathrm{c} .699 \mathrm{~T}>\mathrm{C}$ that associated with increasing SB. It remains unclear whether the $M s p \mathrm{I}-\mathrm{c} .677 \mathrm{~T}>\mathrm{C}$ and $M s p \mathrm{I}-\mathrm{c} .699 \mathrm{~T}>\mathrm{C}$ haplotype polymorphisms have direct impact on the function of the FTH gene and thus in the modulation of SB. Associations between genetic polymorphisms and litter traits in sows are an important step into understanding the genetics of complex traits that are commercially important. Although the results of this study suggest that FTH gene influence economically important traits, the mechanisms of these genetic changes remain unclear because most of them do not cause amino acid changes. It is possible that they affect the transcription of the genes, splicing, mRNA stability, or even translation. As more knowledge is available on how non-coding sequences affect gene function, it may become apparent how these SNP are contributing to variation in these traits. It is also possible that they are linked to other causative mutations that have not been found yet. In the present study not only revealed the primary function of the $F T H$ gene in the pig, but also benefited the selection of sows for low SB by identifying the molecular genetic markers.

It was concluded that molecular approach, PCR-SSCP, has been potentially SNPs detection in commercial sows. This study was found that haplotype of MspI-FTH associated with SB on gilt and sows by using PCR-SSCP technique. However, the polymorphisms in the gene studied may not directly affect the trait. These polymorphisms could be markers linked with causative mutation within the gene or a closely linked gene. It would be of interest to examine the association between $M s p I-F T H$ and these traits in other populations and to extend research with a large number of animals to confirm the results of this study. Moreover, it should be focused at the analysis of high number of genes in order to identify gene interaction network and to describe metabolism of gene activities.

\section{References}

Alschul SF., Madden TL., Schaffer AA., Zhang J., Zhang Z., Miller W. \& Lipman DJ. (1997). Gapped BLAST and PSI-BLAST: a new generation of protein database search programs. Nucleic Acids Research, 1: 3389-3402. http://www.dx.doi.org/10.1093/nar/25.17.3389.

Armersham. (1989). PCR product analysis: a guide to using semidry flatbed gel electrophoresis in Guidebook electrophoresis techniques, 80-6437-96/Rev. A/10-98.

Bertani GR., Gladney CR., Johnson RK. \& Pomp D. (2004). Evaluation of gene expression in pigs selected for enhanced reproduction using differential display PCR: II. Anterior pituitary. Journal of Animal Science, 82: 32-40. http://jas.fass.org/cgi/content/full/82/1/32.

Bensidhoum M., Larou M., Lemeur M., Dierich A., Costet P., Raymond S., Daniel JY., Verneuil H. \& Ged C. (1998). The disruption of mouse uroporphyrinogen III synthase (uros) gene is fully lethal. Transgenics, 2: 275-280.

Bolet G., Bidanel JP. \& Ollivier L. (2001). Selection for litter size in pigs. II. Efficiency of closed and open selection lines. Genetics Selection and Evolution, 33: 515-528. http://www.dx.doi.org/10.1186/1297-9686-33-5-515.

Broyles RH., Belegu V., DeWitt CR., Shah SN., Stewart CA., Pye QN. \& Floyd RA. (2001). Specific repression of $\beta$-globin promoter activity by nuclear ferritin. Proceeding of National of Academic Science. 98: 9145-9150. http://www.dx.doi.org/10.1073ypnas.151147098.

Canario L., Roy N., Gruand J. \& Bidanel JP. (2006). Genetic variation of farrowing kinetics traits and their relationships with litter size and perinatal mortality in French Large White sows. Journal of Animal Science, 84: 1053-1058, http://jas.fass.org/cgi/content/full/84/5/1053.

Cassady JP., Johnson RK., Pomp D., Rohrer GA., van Vleck LD., Spiegel EK. \& Gilson KM. (2001). Identification of quantitative trait loci affecting reproductive in pigs. Journal of Animal Science, 79: 623-633, http://jas.fass.org/cgi/reprint/79/3/623.

Chen CZ., Li L., Lodish HF. \& Bartel DP. (2004). MicroRNAs modulate hematopoietic lineage differentiation. Science, 303: 83-86. http://www.dx.doi.org./10.1126/science.1091903.

de Koning DJ., Rattink AP., Harlizius B., Groenen MAM, Brascamp EW. \& van Arendonk JAM. (2001). Detection and characterization of quantitative trait loci for growth and reproduction traits in pigs. Livestock Production Science, 72: 185-198. http://www.dx.doi.org/ S0301-6226(01)00226-3. 
de Vries AG., Faucitano L., Sosnicki A. \& Plastow GS. (2000). The use of gene technology for optimal development of pork meat quality. Food Chemistry. 69: 397-405. http://www.dx.doi.org/10.1016/S0308-8146(00)00049-2.

Eisenstein RS. (2000). Iron regulatory proteins and the molecular control of mammalian iron metabolism. Annuals Review of Nutrition, 20: 627-662. http://www.dx.doi.org/10.1146/annurev.nutr.20.1.627.

Falconer DS. \& Mackay TFC. (1996). Introduction to quantitative genetics. $4^{\text {th }}$ Ed. Addison Wesley Limiter, Edinburg Gate, Harlow Essex, U.K.

Ferreira C., Bucchini D., Martin ME., Levi S., Arosio P., Grandchamp B. \& Beaumont C. (2000). Early embryonic lethality of $\mathrm{H}$ ferritin gene deletion in mice. The Journal of Biological Chemsitry, 275: 3021-3024. http://www.dx.doi.org/10.1074/jbc.275.5.3021.

Ferreira C., Santambrogio P., Martin ME., Andrieu V., Feldmann G., Henin D. \& Beaumont C. (2001). H ferritin knockout mice: a model of hyperferritinemia in the absence of iron overload. Blood, 98: 525-532. http://www.dx.doi.org/10.1182/blood.V98.3.525.

Freking BA., Leymaster KA., Vallet JL. \& Christenson RK. (2007). Number of fetuses and conceptus growth throughout gestation in lines of pigs selected for ovulation rate or uterine capacity. Journal of Animal Science, 85: 2093-2103. http://www.dx.doi.org/10.2527/jas.2006-766.

Fujita K. \& Silver J. (1994). Single-strand conformational polymorphism. Genome Research, 4: S137-S140.

Hayashi K. (1992). PCR-SSCP: a simple and sensitive method for detection of mutations in the genomic DNA. Genome Research, 1: 34-38.

Imboonta N., Rydhmer L. \& Tumwasorn S. (2007). Genetic parameters for reproduction and production traits of Landrace sows in Thailand. Journal of Animal Science, 85: 53-59. http://www.dx.doi.org/10.2527/jas.2005-708.

Johnson RK., Mielsen MK. \& Casey DS. (1999). Responses in ovulation rate, embryonal survival and litter traits in swine to 14 generations of selection to increase litter size. Journal of Animal Science, 77: 541-557.

King AH., Jiang Z., Gibson JP., Haley CS. \& Archibald AL. (2003). Mapping quantitative trait loci affecting female reproductive traits on porcine chromosome 8. Biology of Reproduction, 68: 2172-2179. http://www.dx.doi.org/10.1095/biolreprod.102.012955.

Li K., Ren J., Xing Y., Zhang Z., Ma J., Guo Y. \& Huang L. (2009). Quantitative trait loci for litter size and prenatal loss in a White Duroc X Chinese Erhualian resource population. Animal Genetics. 40: 963-966. http://www.dx.doi.org/10.1111/j.1365-2052.2009.01931.x.

Leibold EA. \& Munro HN. (1988). Cytoplasmic protein binds in vitro to a highly conserved sequence in the 5-prime untranslated region of ferritin heavy- and light-subunit mRNAs. Proceeding of National of Academic Science, 85: 2171-2175.

Linderman M.D. (1993). Supplemental folic acid: A requirement for optimizing swine reproduction. Journal of Animal Science, 71: 239-246.

Linville RC., Pomp D., Johnson RK. \& Rothschild MF. (2001). Candidate gene analysis for loci affecting litter size and ovulation rate in swine. Journal of Animal Science, 79: 60-67.

Mahan DC. \& Vallet JL. (1997). Vitamin and mineral transfer during fetal development and the early postnatal period in pigs. Journal of Animal Science, 75: 2731-2738.

Merks JWM., Ducro-Steverink DWB. \& Feitsma H. (2000). Management and genetic factors affecting fertility in sows. Reproductive Domestic Animal, 35: 261-266. http://www.dx.doi.org/10.1046/j.1439-0531.2000.00269.x.

Moeller SJ., Goodwin RN., Johnson RK., Mabry JW., Baas TJ. \& Robison OW. (2004). The national pork producers council maternal line national genetic evaluation program: a comparison of six maternal genetic lines for female productivity measures over four parities. Journal of Animal Science, 82: 41-53, http://jas.fass.org/cgi/content/full//82/1/41.

Moore RW., Redmond HE. \& Livingston CW. Jr. (1965). Iron deficiency anemia as a cause of stillbirths in swine. Journal of the American Veterinary Medical Association, 1: 746-748.

Oppenheim EW., Adelman C., Liu X. \& Stover PJ. (2001). Heavy chain ferritin enhances serine hydroxymethyltransferase expression and de novo thymidine biosynthesis. Journal of Biological Chemistry, 276: 19855-19861. http://www.dx.doi.org/10.1074/jbc.M100039200.

Orita M., Suzuki Y., Sekiya T. \& Hayashi K. (1997). Rapid and sensitive detection of point mutations and DNA polymorphisms using the polymerase chain reaction. Genomics, 5: 874-879. 
Orita M., Iwahana H., Kanazawa H., Hayashi K. \& Sekiya T. (1989). Detection of polymorphisms of human DNA by gel electrophoresis as single-strand conformation polymorphisms. Proceeding of National of Academic Science, 86: 2766-2770.

Pearson PL., Klemcke HG., Christenson RK. \& Vallet JL. (1998). Uterine environment and breed effects on erythropoiesis and liver protein secretion in late embryonic and early fetal swine. Biology of Reproduction, 58: 911-918. http://www.dx.doi.org/10.1095/biolreprod58.4.911.

Pham CG., Bubici C., Zazzeroni F., Papa S., Jones J., Alvarez K., Jayawardena S., De Smaele E., Cong R., Beaumont C., Torti FM., Torti SV. \& Franzoso G. (2004). Ferritin heavy chain upregulation by NF-kappa-B inhibits TNF-alpha-induced apoptosis by suppressing reactive oxygen species. Cell, 119: 529-542. http://www.dx.doi.org/10.1016/j.cell.2004.10.017.

Ponsuksili S., Chomdej S., Schellander K. \& Wimmers K. (2002). SNP detection and linkage mapping of the porcine ferritin heavy-chain gene. Animal Genetics, 33: 325-326. http://www.dx.doi.org/10.1046/j.1365-2052.2002.t01-13-00886.x.

Rothschild MF. (1996). Genetics and reproduction in the pig. Animal Reproduction Science, 42: 143-151.

Sherman EL., Nkrumah JD., Murdoch BM., Li C., Wang Z., Fu A. \& Moore SS. (2008). Polymorphisms and haplotypes in the bovine neuropeptide Y, growth hormone receptor, ghrelin, insulin-like growth factor 2, and uncoupling proteins 2 and 3 genes and their associations with measures of growth, performance, feed efficiency, and carcass merit in beef cattle. Journal of Animal Science. 86: 1-16. http://www.dx.doi.org/10.2527/jas.2006-799.

Skinner CA., Rubsby G. \& Honour JW. (1996). Single strand conformation polymorphism (SSCP) analysis for the detection of mutations in the CYP11B1 gene. Journal of Clinical Endocrinology and Metabolism, 81: 2389-2393.

Spotter A. \& Distl O. (2006). Genetic approaches to the improvement of fertility traits in the pig, The Veterinary Journal, 172: 234-247. http://www.dx.doi.org/10.1016/j.tvj1.2005.11.013.

Sunnucks P., Wilson ACC., Beheregaray LB., Zenger K., French J. \& Taylor AC. (2000). SSCP is not so difficult: the application and utility of single-stranded conformation polymorphism in evolutionary biology and molecular ecology. Molecular Ecology, 9: 1699-1710. http://www.dx.doi.org/10.1046/j.1365-294x.2000.01084.x.

Torti FM. \& Torti SV. (2002). Regulation of ferritin genes and protein. Blood, 99: 3505-3516. http://www.dx.doi.org/10.1182/blood.V99.10.3505.

Vallet JL., Klemcke HG., Christenson RK. \& Pearson PL. (2003). The effect of breed and intrauterine crowding on fetal erythropoiesis on day 35 of gestation in swine. Journal of Animal Science, 81: 2352-2356, http://jas.fass.org/cgi/content/full/81/9/2352.

Valeh MV., Tahmoorespour M., Ansari M., Nassiry MR., Karimi D. \& Taheri A. (2009). Association of growth traits with SSCP polymorphisms at the growth hormone receptor (GHR) and growth hormone releasing hormone receptor (GHRHR) genes in the Baluchi sheep. Journal of Animal and Veterinary Advances, 8: 1063-1069.

Vonnahme KA., Wilson ME., Foxcroft GR. \& Ford SP. (2002). Impacts on conceptus survival in a commercial swine herd. Journal of Animal Science, 80: 553-559.

Walsh PS., Metzger DA. \& Higuchi R. (1991). Chelex 100 as a medium for simple extraction of DNA for PCR-based typing from forensic material. Biotechniques, 10: 506-513.

Wilkie PJ., Paszek AA., Beattie CW., Alexander LJ., Wheeler MB. \& Schook LB. (1999). A genomic scan of porcine reproductive traits reveals possible quantitative trait loci (QTLs) for number of corpora lutea. Mammalian Genome, 10: 573-578. http://www.dx.doi.org/10.1007/s003359901047.

Williams AE. (2008). Functional aspects of animal micro RNAs. Cellular and Molecular Life Sciences, 65: 545-562. http://www.dx.doi.org/10.1007/s00018-007-7355-9.

Woeller CF., Fox JT., Perry C. \& Stover PJ. (2007). A ferritin-responsive internal ribosome entry site regulates folate metabolism. Journal of Biological Chemistry, 82: 29927-29935, doi: 10.1074/jbc.M706264200, http://www.dx.doi.org/10.1074/jbc.M706264200.

Yao J., Aggrey SE., Zadwormy D., Hayes JF. \& Kuhnlein R. (1996). Sequence variation in the bovine growth hormone gene characterized by single-strand conformation polymorphism (SSCP) analysis and their association with milk production traits in Holsteins. Genetics, 144: 1809-1816.

Zhang KH., Tian HY., Gao X., Lei WW., Hu Y., Wang DM., Pan XC., Yu ML., Xu GJ., Zhao FK. \& Song JG. (2009). Ferritin heavy chain-mediated iron homeostasis and subsequent increased reactive oxygen species 
production are essential for epithelial-mesenchymal transition. Cancer Research, 69: 5340-5348. http://www.dx.doi.org/10.1158/0008-5472.CAN-09-0112.

Table 1. Phenotype data of piglet number related traits on parent stock of commercial pig

\begin{tabular}{|l|c|c|c|c|c|c|c|}
\hline \multicolumn{1}{|c|}{ Trait } & Abbr. & Units & N & Min & Max & Mean & SD \\
\hline Total number of piglets born alive & TNB & Piglets & 5,102 & 1.00 & 20.00 & 11.30 & 3.00 \\
\hline Number of piglets born alive & NBA & Piglets & 5,102 & 0.00 & 19.00 & 10.02 & 3.00 \\
\hline Stillborn piglets & SB & Piglets & 5,102 & 0.00 & 13.00 & 0.88 & 1.14 \\
\hline Mummified piglets & MM & Piglets & 5,102 & 0.00 & 13.00 & 0.39 & 1.15 \\
\hline
\end{tabular}

Table 2. Primers sequence and PCR condition of $F T H$

\begin{tabular}{|c|c|c|}
\hline primer & $\begin{array}{l}\text { Forward primer } \\
\text { Reverse primer }\end{array}$ & Condition \\
\hline FTH1 & ggtttcetgcttcaacagtg tcagcccattctcccagtc & $95 \mathrm{C} 30 \mathrm{~s} / 58 \mathrm{C} 45 \mathrm{~s} / 72 \mathrm{C} 60 \mathrm{~s}) \times 38 \mathrm{cyc}$ \\
\hline FTH2 & tgagaaactgatgaagctgc ggtaacccgaa & $(95 \mathrm{C} 30 \mathrm{~s} / 58 \mathrm{C} 45 \mathrm{~s} / 72 \mathrm{C} 45 \mathrm{~s}) \times 30$ cycles \\
\hline FTH3 & tcagagecagecctcacc gatatcctgaagga & $(95 \mathrm{C} 30 \mathrm{~s} / 60 \mathrm{C} 45 \mathrm{~s} / 72 \mathrm{C} 45 \mathrm{~s}) \times 38$ cycles \\
\hline FTH4 & aaaccggagcgcgatgac gtgggggtcatttttgtcag & $(95 \mathrm{C} 30 \mathrm{~s} / 58 \mathrm{C} 30 \mathrm{~s} / 72 \mathrm{C} 45 \mathrm{~s}) \times 32$ cycles \\
\hline FTH5 & tgtgtgacttcattgagacg ggaatggtacactaaggaaag & $(95 \mathrm{C} 30 \mathrm{~s} / 58 \mathrm{C} 45 \mathrm{~s} / 72 \mathrm{C} 45 \mathrm{~s}) \times 38$ cycles \\
\hline FTH6 & ggcggtttcctgcttcaac ggtgagggctggctctga & $(95 \mathrm{C} 30 \mathrm{~s} / 60 \mathrm{C} 45 \mathrm{~s} / 72 \mathrm{C} 60 \mathrm{~s}) \times 28$ cycles \\
\hline FTH7 & cgaatcttccttcaggatatc tcceagtcatcgegctcc & $(95 \mathrm{C} 30 \mathrm{~s} / 60 \mathrm{C} 45 \mathrm{~s} / 72 \mathrm{C} 60 \mathrm{~s}) \times 38$ cycles \\
\hline FTH8 & ctgacaaaaatgacccccac gegtctcaatgaagtcacac & $(95 \mathrm{C} 30 \mathrm{~s} / 60 \mathrm{C} 30 \mathrm{~s} / 72 \mathrm{C} 30 \mathrm{~s}) \times 32$ cycles \\
\hline FTH9 & tgggtgaccacattaccaac aggtgacggtaacccgaaac & $(95 \mathrm{C} 30 \mathrm{~s} / 60 \mathrm{C} 45 \mathrm{~s} / 72 \mathrm{C} 60 \mathrm{~s}) \times 38$ cycles \\
\hline
\end{tabular}

Table 3. Genotype and allele frequency of porcine $M s p \mathrm{I}-F T H$

\begin{tabular}{|c|c|c|c|c|}
\hline Haplotype & Genotype frequency & Cumulative frequency & Allele frequency & $\chi^{2}$ \\
\hline TT/TT & 42 & 42 & \multirow{6}{*}{$\begin{array}{l}\mathrm{f}(\mathrm{a})=0.22 \\
\mathrm{f}(\mathrm{b})=0.35 \\
\mathrm{f}(\mathrm{c})=0.43\end{array}$} & \multirow{6}{*}{$\begin{array}{c}5,970.38(\mathrm{df}=5) \\
\mathrm{P}<0.0001\end{array}$} \\
\hline TT/TC & 260 & 302 & & \\
\hline $\mathrm{TC} / \mathrm{CC}$ & 259 & 561 & & \\
\hline TC/TC & 41 & 602 & & \\
\hline $\mathrm{TC} / \mathrm{CC}$ & 593 & 1,195 & & \\
\hline $\mathrm{CC} / \mathrm{CC}$ & 166 & 1,361 & & \\
\hline
\end{tabular}

Table 4. Piglet number traits on parent stock of commercial pigs on Msp I-FTH

\begin{tabular}{|l|c|c|c|c|c|c|}
\hline \multirow{2}{*}{ Traits } & \multicolumn{7}{|c|}{ Haplotype } \\
\cline { 2 - 7 } & TT/TT & TT/TC & TT/CC & TC/TC & TC/CC & CC/CC \\
\hline TNB & $11.32 \pm 0.21$ & $11.46 \pm 0.09$ & $11.31 \pm 0.09$ & $11.61 \pm 0.26$ & $11.36 \pm 0.06$ & $11.18 \pm 0.12$ \\
\hline NBA & $10.23 \pm 0.21$ & $10.22 \pm 0.09$ & $10.16 \pm 0.09$ & $10.13 \pm 0.24$ & $10.18 \pm 0.06$ & $10.05 \pm 0.13$ \\
\hline SB & $0.88 \pm 0.09^{\mathrm{a}}$ & $0.89 \pm 0.04^{\mathrm{a}}$ & $0.80 \pm 0.03^{\mathrm{a}}$ & $1.09 \pm 0.12^{\mathrm{b}}$ & $0.84 \pm 0.02^{\mathrm{a}}$ & $0.81 \pm 0.05^{\mathrm{a}}$ \\
\hline MM & $0.21 \pm 0.05$ & $0.35 \pm 0.03$ & $0.35 \pm 0.03$ & $0.40 \pm 0.08$ & $0.35 \pm 0.02$ & $0.31 \pm 0.04$ \\
\hline
\end{tabular}

${ }^{\mathrm{a}, \mathrm{b}}$ LSMeans_SEM within row with different superscripts significantly differed $(\mathrm{P}<0.05)$.

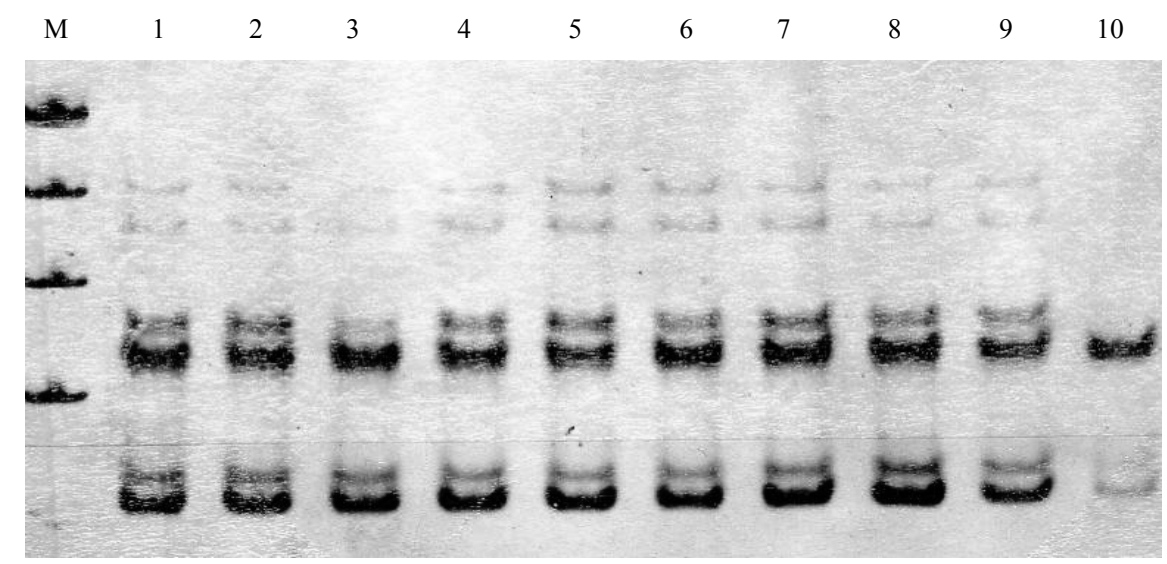

Figure 1. PCR-SSCP analysis of $F T H . \mathrm{M}=$ markers $100 \mathrm{bp}$, lane 1-5 = low TNB sows, lane 6-10 = high TNB sows 